\title{
SHCAL04 SOUTHERN HEMISPHERE CALIBRATION, 0-11.0 CAL KYR BP
}

\author{
F G McCormac ${ }^{1,2} \bullet \mathrm{A} \mathrm{G} \mathrm{Hogg}^{3} \bullet$ P G Blackwell ${ }^{4}$ C E E Buck ${ }^{4}$ T F G Higham ${ }^{5}$ P J Reimer 1,6
}

ABSTRACT. Recent measurements on dendrochronologically-dated wood from the Southern Hemisphere have shown that there are differences between the structural form of the radiocarbon calibration curves from each hemisphere. Thus, it is desirable, when possible, to use calibration data obtained from secure dendrochronologically-dated wood from the corresponding hemisphere. In this paper, we outline the recent work and point the reader to the internationally recommended data set that should be used for future calibration of Southern Hemisphere ${ }^{14} \mathrm{C}$ dates.

\section{INTRODUCTION}

Hogg et al. (2002) and McCormac et al. (1998) have measured the radiocarbon activity of decadal paired samples of wood from the Northern and Southern Hemispheres for the period AD 1950-950. Their results show that the concept of a fixed offset between the hemispheres that can be used to adjust the Northern Hemisphere calibration data to calibrate Southern Hemisphere measurements is erroneous, as significant temporal variations in the magnitude of the hemispheric offset exist. The calibration of Southern Hemisphere measurements is therefore best achieved using securely dendrochronologically-dated wood on which replicate ${ }^{14} \mathrm{C}$ measurements have been made. The Southern Hemisphere is here defined as south of the thermal equator or the Intertropical Convergence Zone (ITCZ).

\section{INTCAL04 WORKSHOP AND RADIOCARBON CONFERENCE 2003 RECOMMENDATIONS}

Two workshops to review and discuss recent developments and data relating to ${ }^{14} \mathrm{C}$ calibration were convened at Queen's University Belfast and Woods Hole Oceanographic Institute during 2002 and 2003 (Reimer et al. 2002, 2003). The international group of participants reviewed data from the present to beyond $25 \mathrm{kyr}$ BP. Sections of the calibration curve, including those that used dendrochronological data, were discussed and agreed upon for inclusion. The data relating to the Southern Hemisphere, including the results from McCormac et al. (1998) and Hogg et al. (2002) on New Zealand trees covering 0-1000 cal BP; data from the University of Washington Quaternary Isotope Laboratory from Chilean and Tasmanian wood from 0-290 cal BP and 0-55 cal BP, respectively [McCormac et al. (2002); New Zealand measurements of Sparks et al. (1995)]; and South African measurements from 115-51 cal BP from Pretoria (Vogel et al. 1993), were considered. Comparisons between these data sets were given in Table 2 of McCormac et al. (2002).

It was agreed that the combined set of measurements for Southern Hemisphere wood should form a single calibration, provided the measurements from different laboratories showed good relative consistency, i.e. interlaboratory offsets were small. Ratification was obtained at the International Radiocarbon Conference in Wellington, New Zealand (2003) to recommend the use of the Southern Hemisphere data from cal AD 1950-950 (0-1000 cal BP) given in McCormac et al. (2002), combined via a random walk model using the same parameters as for IntCal04, the Northern Hemisphere atmospheric data set (Buck and Blackwell, this issue).

\footnotetext{
${ }^{1}$ School of Archaeology and Palaeoecology, Queen's University Belfast, Belfast BT7 1NN, United Kingdom.

${ }^{2}$ Corresponding author. Email: f.mccormac@qub.ac.uk.

${ }^{3}$ Radiocarbon Dating Laboratory, University of Waikato, Private Bag 3105, Hamilton, New Zealand.

${ }^{4}$ Department of Probability and Statistics, University of Sheffield, Sheffield S3 7RH, United Kingdom.

${ }^{5}$ Oxford Radiocarbon Accelerator Unit, 6 Keble Rd., Oxford OX2 6JB, England.

${ }^{6}$ Center for Accelerator Mass Spectrometry L-397, Lawrence Livermore National Laboratory, Livermore, California 94550, USA.
} 


\section{Calibration Curve Construction}

In addition to the Southern Hemisphere data given in McCormac et al. (2002), a few measurements of nineteenth- and twentieth-century wood from the Cape Town tree Pretoria data set (A S Talma, personal communication) have been included. To account for additional sources of uncertainty beyond the counting error, we use laboratory error multipliers of 1.0 for the Pretoria, Waikato, and Belfast data sets, and 1.2 for the Seattle data set as estimated from interlaboratory comparisons (McCormac et al. 2002). As in the IntCal04 calibration data set (Reimer et al., this issue), the uncertainty in the cal ages was assumed to be on the order of 1 or $2 \mathrm{yr}$ and was therefore neglected in the analysis. The calendar age span of each measurement (e.g. number of tree rings) was taken into account in the random walk model (Buck and Blackwell, this issue).

The offset with the Northern Hemisphere is not constant but ranges from 1 to $10 \%$ o $\left(8-80{ }^{14} \mathrm{C} \mathrm{yr}\right)$. Rather than using an average offset to estimate the Southern Hemisphere calibration curve from the IntCal04 data set beyond the range of the Southern Hemisphere tree-ring measurements, a random effects model (Buck and Blackwell, this issue) is used to take account of the fact that the offset may vary slowly over time within the constraint of the offset observed from 50-1000 cal BP. The modeled offset varies only slightly from 55 to $58 \mathrm{yr}$, but the uncertainty increases from \pm 7.9 at $1000 \mathrm{cal} \mathrm{BP}$ to \pm 25 at $11,000 \mathrm{cal} \mathrm{BP}$. The modeled offset is larger than the previously published average offset of $41 \pm 14$ (McCormac et al. 2002) but reflects the trend of the offset from 50-990 cal BP. While past changes in ocean circulation may have altered the interhemispheric offset, we note that measurements for the early Holocene are of the same order of magnitude (Kromer et al. 1998; Barbetti et al. 2004).

\section{DISCUSSION}

On the basis of a global transport model, the Southern Hemisphere atmosphere was predicted to have greater pre-industrial latitude-dependent ${ }^{14} \mathrm{C}$ offsets than the Northern Hemisphere, especially in the high latitudes (Braziunas et al. 1995). No pre-industrial calibration records are currently available from the high or low latitudes in the Southern Hemisphere, although measurements of postbomb atmospheric ${ }^{14} \mathrm{CO}_{2}$ samples suggest a ${ }^{14} \mathrm{C}$ gradient from $40-70^{\circ} \mathrm{S}$ (Levin and Hesshaimer 2000). However, no statistically significant difference was observed in tree rings from New Zealand $\left(40^{\circ} \mathrm{S}\right)$ and Chile $\left(55^{\circ} \mathrm{S}\right)$ from AD $1650-1850$ (McCormac et al. 2002). Measurements of post-bomb atmospheric $\mathrm{CO}_{2}$ from sites from $20-45^{\circ} \mathrm{S}$ show similar timing and magnitude of the ${ }^{14} \mathrm{C}$ peak (Hua and Barbetti, this issue). Thus, as for the Northern Hemisphere, we assume a well-mixed atmosphere for the mid-latitude sites used for construction of the Southern Hemisphere calibration data set, which currently extends to $1000 \mathrm{cal}$ BP (McCormac et al. 2002).

The distinction between the Southern and Northern Hemisphere atmosphere should actually be considered to lie along the thermal equator or the Intertropical Convergence Zone (ITCZ) during the respective growing seasons, rather than at the geographic Equator. This poses an additional uncertainty for calibration of ${ }^{14} \mathrm{C}$ data from tropical and neo-tropical sites where growing seasons may be less distinct than at temperate sites. The seasonal shift in the ITCZ may bring atmospheric $\mathrm{CO}_{2}$ from the Northern Hemisphere to a site for part of the year and from the Southern Hemisphere for another part. This has been observed in ${ }^{14} \mathrm{C}$ from trees growing in Panama (Westbrook et al., forthcoming) and in Thailand (Hua et al. 2002). Evidence for migration of the ITCZ on multi-decadal to millennial time scales has been seen in proxy records from around the globe (Arz et al. 1998; Haug et al. 2001; Hodell et al. 2001; Luckge et al. 2001; Marret et al. 2001; Maslin and Burns 2000; Wang et al. 2004). It is beyond the scope of IntCal to determine the location of the paleo-ITCZ, but those who wish to develop chronologies for records in this region should be aware of this complication. 


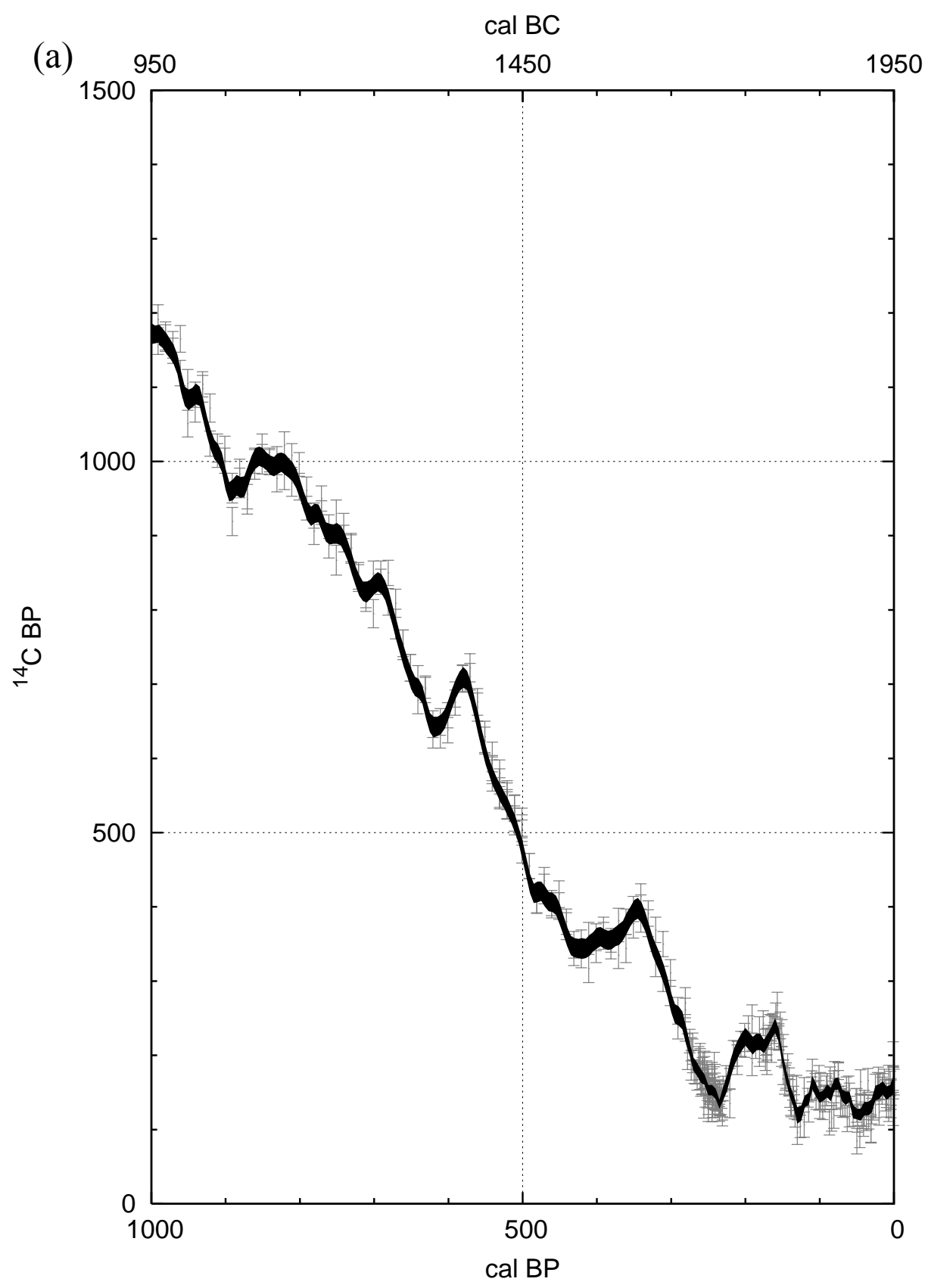

Figure 1a Southern Hemisphere radiocarbon calibration curve SHCal04 (1-standard deviation envelope) based on Southern Hemisphere tree-ring measurements from 0 to $1000 \mathrm{cal} \mathrm{BP}$. Individual measurements are shown with 1-standard deviation error bars in ${ }^{14} \mathrm{C}$ age including the laboratory error multipliers (see text). The calendar age span (e.g. number of tree rings) for each sample is not shown, but is taken into account in the random walk model. The calibration curve beyond the end of the tree-ring data set at $1000 \mathrm{cal} \mathrm{BP}$ is based on the offset from the Northern Hemisphere data set (IntCal04) calculated with a random effects model (Buck and Blackwell, this issue). 
(b)

cal BC

50

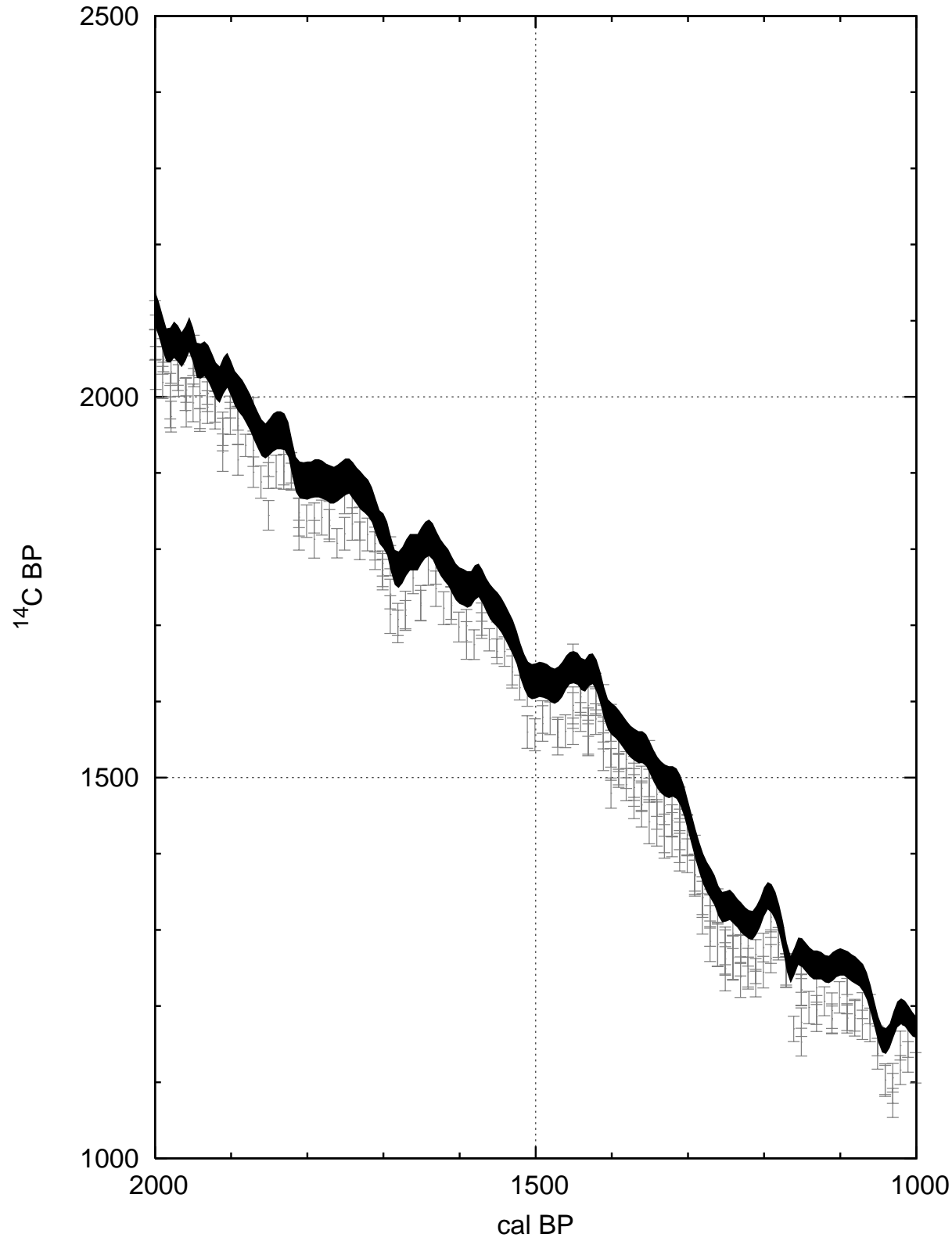

Figure 1b Southern Hemisphere radiocarbon calibration curve SHCal04 (1-standard deviation envelope) based on IntCal04 Northern Hemisphere tree-ring measurements from 1000 to $2000 \mathrm{cal}$ BP. Individual measurements are shown with 1-standard deviation error bars in ${ }^{14} \mathrm{C}$ age including the laboratory error multipliers (see text). The calendar age span (e.g. number of tree rings) for each sample is not shown, but is taken into account in the random walk model. The calibration curve beyond the end of the tree-ring data set at $1000 \mathrm{cal}$ BP is based on the offset from the Northern Hemisphere data set (IntCa104) calculated with a random effects model (Buck and Blackwell, this issue). Because the offset from IntCal04 is essentially constant, we do not plot the entire calibration data set. 
The SHCal04 data set and calibration curve is plotted for 0 to 2 cal kyr BP (Figure 1). The data are not published here but are available at www.radiocarbon.org and www.calib.org. The calibration data set is recommended for use in future calibration of Southern Hemisphere measurements back to 11.0 cal kyr BP. Before the Holocene, larger-scale carbon reservoirs changes may have altered the interhemispheric offset. We therefore do not recommend Southern Hemisphere calibration beyond $11.0 \mathrm{cal} \mathrm{kyr} \mathrm{BP}$, but note that the average offset for the last $500 \mathrm{yr}$ of the modeled data set SHCal04 is $56 \pm 24$. The additional uncertainty in the Southern Hemisphere calibration data set beyond the measured tree-ring data will, of course, increase calibrated age ranges compared to those from the Northern Hemisphere which utilize IntCal04. The international research funding bodies should be encouraged to support efforts to develop and extend dendrochronological records from the Southern Hemisphere.

\section{ACKNOWLEDGMENTS}

This work was supported by 2 grants to Drs A G Hogg and T F G Higham at the University of Waikato; by the New Zealand Foundation for Research Science and Technology, Grant numbers UOW-508 \& UOW-609; and by a research grant from the Natural Environment Research Council, Grant nr GR9/02597 to Prof F G McCormac at Queen's University Belfast. A portion of this work was performed under the auspices of the U S Department of Energy by the University of California, Lawrence Livermore National Laboratory under Contract No. W-7405-Eng-48. We appreciate the additional information on the Cape Town tree and Pretoria measurements, which were provided by A S Talma and J C Vogel.

\section{REFERENCES}

Arz HW, Patzold J, Wefer G. 1998. Correlated millennialscale changes in surface hydrography and terrigenous sediment yield inferred from last-glacial marine deposits off northeastern Brazil. Quaternary Research 50:157-66.

Barbetti M, Hua Q, Zoppi U, Fink D, Zhao Y, Thomson B. 2004. Radiocarbon variations from the Southern Hemisphere, 10,350-9700 cal BP. Nuclear Instruments \& Methods in Physics Research Section BBeam Interactions with Materials and Atoms 223-24: 366-70.

Braziunas TF, Fung IY, Stuiver M. 1995. The preindustrial atmospheric ${ }^{14} \mathrm{CO}_{2}$ latitudinal gradient as related to exchanges among atmospheric, oceanic, and terrestrial reservoirs. Global Biogeochemical Cycles 9:56584.

Buck CE, Blackwell PG. 2004. Formal statistical models for estimating radiocarbon calibration curves. Radiocarbon, this issue.

Haug GH, Hughen KA, Sigman DM, Peterson LC, Rohl U. 2001. Southward migration of the Intertropical Convergence Zone through the Holocene. Science 293:1304-8

Hodell DA, Brenner M, Curtis JH, Guilderson T. 2001. Solar forcing of drought frequency in the Maya lowlands. Science 292:1367-70.

Hogg AG, McCormac FG, Higham TFG, Reimer PJ, Baillie MGL, Palmer JG. 2002. High-precision radiocarbon measurements of contemporaneous tree-ring dated wood from the British Isles and New Zealand: AD 1850-950. Radiocarbon 44(3):633-40.

Hua Q, Barbetti M. Review of tropospheric bomb ${ }^{14} \mathrm{C}$ data for carbon cycle modeling and age calibration purposes. Radiocarbon, this issue.

Hua Q, Barbetti M, Zoppi U, Fink D, Jacobsen G. 2002. Radiocarbon in tropical tree rings during the Little Ice Age. In: Abstracts for the Ninth International Conference on Accelerator Mass Spectrometry (AMS-9). Nagoya, Japan.

Kromer B, Spurk M, Remmele S, Barbetti M. 1998. Segments of atmospheric ${ }^{14} \mathrm{C}$ change as derived from late glacial and early Holocene floating tree-ring series. Radiocarbon 40(1):351-8.

Levin I, Hesshaimer V. 2000. Radiocarbon-a unique tracer of global carbon cycle dynamics. Radiocarbon 42(1):69-80.

Luckge A, Doose-Rolinski H, Khan AA, Schulz H, von Rad U. 2001. Monsoonal variability in the northeastern Arabian Sea during the past 5000 years: geochemical evidence from laminated sediments. Palaeogeography, Palaeoclimatology, Palaeoecology 167:27386.

Marret F, Scourse JD, Versteegh G, Jansen JHF, Schneider R. 2001. Integrated marine and terrestrial evidence for abrupt Congo River palaeodischarge fluctuations during the last deglaciation. Journal of Quaternary Science 16:761-6.

Maslin MA, Burns SJ. 2000. Reconstruction of the Am- 
azon Basin effective moisture availability over the past 14,000 years. Science 290:2285-7.

McCormac FG, Hogg AG, Higham TFG, Lynch-Stieglitz J, Broecker WS, Baillie MGL, Palmer J, Xiong L, Pilcher JR, Brown D, Hoper ST. 1998. Temporal variation in the interhemispheric C-14 offset. Geophysical Research Letters 25:1321-4.

McCormac FG, Reimer PJ, Hogg AG, Higham TFG, Baillie MGL, Palmer J, Stuiver M. 2002. Calibration of the radiocarbon time scale for the Southern Hemisphere: AD 1850-950. Radiocarbon 44(3):641-51.

Reimer PJ, Hughen KA, Guilderson TP, McCormac FG, Baillie MGL, Bard E, Barratt P, Beck JW, Buck CE, Damon PE, Friedrich M, Kromer B, Bronk Ramsey C, Reimer RW, Remmele S, Southon JR, Stuiver M, van der Plicht J. 2002. Preliminary report of the first workshop on the IntCal04 Radiocarbon Calibration/Comparison Working Group. Radiocarbon 44(3):653-61.

Reimer PJ, Baillie MGL, Bard E, Beck JW, Blackwell, PG, Buck CE, Damon PE, Fairbanks, RG, Friedrich M, Guilderson TP, Hogg AG, Hughen KA, Kromer B, McCormac FG, Bronk Ramsey C, Reimer RW, Remmele S, Southon JR, Stuiver M, van der Plicht J, Weyhenmeyer CE. 2003. Extension and revision of the radiocarbon calibration data set: Part 1 IntCal04 12.4-0 ka cal BP. 18th International Radiocarbon Conference,
Wellington, New Zealand, 4 September 2003.

Reimer PJ, Baillie MGL, Bard E, Bayliss A, Beck JW, Bertrand CJH, Blackwell PG, Buck CE, Burr GS, Cutler KB, Damon PE, Edwards RL, Fairbanks RG, Friedrich M, Guilderson TP, Hogg AG, Hughen KA, Kromer B, McCormac FG, Manning SW, Ramsey CB, Reimer RW, Remmele S, Southon JR, Stuiver M, Talamo S, Taylor FW, van der Plicht J, Weyhenmeyer CE. 2004. IntCal04 terrestrial radiocarbon age calibration, 26-0 cal kyr BP. Radiocarbon, this issue.

Sparks RJ, Melhuish WH, McKee JWA, Ogden J, Palmer JG, Molloy BPJ. 1995. ${ }^{14} \mathrm{C}$ calibration in the Southern Hemisphere and the date of the last Taupo eruption: evidence from tree-ring sequences. Radiocarbon 37(2):155-63.

Vogel JC, Fuls A, Visser E, Becker B. 1993. Pretoria calibration curve for short-lived samples 1930-3350 BC. In: Stuiver M, Kra RS, editors. Calibration 1993 issue. Radiocarbon 35(1):73-85.

Wang X, Auler AS, Edwards RL, Cheng H, Cristalli PS, Smart PL, Richards DA, Shen C-C. 2004. Wet periods in northeastern Brazil over the past $210 \mathrm{kyr}$ linked to distant climate anomalies. Nature 432:740-3.

Westbrook JA, Guilderson TP, Colinvaux PA. Forthcoming. Annual growth bands in Hymenaea courbaril. Iawa Journal. 